\title{
Study of Procurement Methods by Purchasing Agreements: A Case Study of Private Corporations in Thailand
}

\author{
Suntaree Puttiworn \\ College of Logistics and Supply Chain, Suan Sunandha Rajabhat University, Nakhonpathom Learning Center, Thailand
}

Copyright $(2016$ by authors, all rights reserved. Authors agree that this article remains permanently open access under the terms of the Creative Commons Attribution License 4.0 International License

\begin{abstract}
A study of procurement methods by purchasing agreements: a case study of private corporations in Thailand. This study is a survey research with three objectives; 1) to study the processes of procurement by purchasing agreements, 2) to study processing time for procurement by purchasing agreements, 3) to study means to improve performance of procurement by purchasing agreements; a case study of international business organization of private corporations in Thailand. Variables are determined as; 1) personal factors (gender, age, education level, experience, and income) as independent variables, 2) detail inspection, bidding documents preparation and contact supplier sources, procurement, receiving inspection, and payment.[14] The results revealed that: General information: There were female more than male that response to the questionnaire, at 60.0 percent, and the respondents were mostly age between 31-40 years old, 17 persons and at 42.5 percent. The results indicated that 18 persons, 45.0 percent, which were the most respondents, were bachelor degree graduates. Furthermore, the most respondents worked at operational level, 19 persons, and 47.5 percent. For experience of the respondent, there were 16 persons, 40 percent, who have worked for at least 1-5 years. Most of the respondents, 11 persons and 27.5 percent, have their income more than 50,000 Baht. Detail inspection: For the detail inspection, most of the respondents have given their highest opinion on procurement staffs that receive online requisition forms from requisite persons, 4.13 percent. The second highest opinion was on detail inspection of the requisition forms, 4.00 percent, and the third highest opinion was on whether audit systems, to guarantee that the regulations were followed, are available, 3.86 percent. And the lowest opinion was given to whether types and amounts were indicated in requirement notification or procurement request, 3.83 percent. Combine mean was 3.96 with deviation 0.72. Bidding documents preparation and contact supplier sources: For bidding documents preparation and contact supplier sources, most respondents found that seller records as well as statistics of price and amount are available
\end{abstract}

has the highest frequency, 3.95 percent. The second highest frequency was estimate cost was indicated in order to compare with offering price, 3.85 percent, and the third highest frequency were comparison to latest buying price and/or from various sellers in order to get the best price possible, and easy to contact with sellers or supplier sources, which have equal mean at 3.82 percent. Combine mean was 3.86 with deviation 0.62 . Procurement: For procurement, the highest opinion from the respondents was given to preparation of purchasing orders and its copies for accessories; which are receiving inspectors, procurement informants, accountants or finances, 4.56 percent. The second highest answer was appropriate procurement, 3.92 percent, and the third highest answer was procurement by procurement staffs under material request forms or approved procurement licenses, 3.82 percent. And the lowest was fast and accurate procurement, 3.80 percent. Combine mean was 4.02 with deviation 1.71. Receiving inspection and payment: For receiving inspection and payment, most of the respondents have given the highest opinion to counting of amounts and types of received material with purchasing orders or invoices, with at least 2 inspectors' signatures, 4.05 percent. The second highest opinion was specifying department that responsible for payment inspection, 4.00 percent, and the third most frequent answer was receipt that has been paid should be marked to avoid repeated payment, 3.95 percent. And the lowest opinion was identifying authorized receiving inspectors, 3.87 percent. Combine mean was 3.96 with deviation 0.62 .

Keywords Procurement, Purchasing, Purchasing Agreements, Processing Time, Supplier Sources

\section{Introduction}

Private corporations in Thailand, which engages in 
logistics and international business, would have domestic supply and procurement department that has duties and responsibilities for domestic procurement, domestic contract administration, and management of all supply categories for all department of affiliates, as comprehensive and effective in terms of quantity, quality, and time. [4] As well as an up-to-date information technology management for supply and procurement system, and being a center for academic data and standard for supply and procurement, has duties and responsibilities for material procurement, hiring and renting for all categories, including hiring a consultant to meet field requirement in terms of quantity, quality, time, and reasonable price.[5]

When Thailand is in recession, many organizations needed to support themselves in order to survive, and many others have closed down their business and lay off their employers. Therefore, in order for the organization to be able to survive, they supposed to reduce costs in all sorts of operation, such as staff wages; utility costs; and production costs, etc. [8] Many organizations have turned to pay more attention on procurement of equipment and production materials, which are production costs, by focusing on finding new ways to reduce equipment and production material costs, including reduction of procurement time, improve price negotiation performance, recruiting quality salesmen and employers, and producing minimum expenses for procurement. [15]

At present, private corporations in Thailand, that engages in logistics and international business, have greatly expand their frameworks, consequently, user departments request for quick processing on procurement of products and service in response to each internal department's requirement. [9],[10] For this reason, procurement department needs to have their plans to improve work performance, and be able to quickly response to user department's requirement and to produce highest satisfaction. [18]

According to the private corporations in Thailand indicated to have various procurement methods, for example, pricing agreement procedure which is facing management problems when not many retailers giving their price quotes; unattractive job value; small quantity; or some jobs require samples which make it is not worth their works. [12]
From this situation, it brought our interest to study on procurement methods of private corporations in Thailand that engages in logistics and international business. The study focused on a case study of procurement by purchasing agreements, in order to conform to development of logistics business and international transportation in Thailand. [1],[2]

\section{Research Objectives}

- To study the processes of procurement by purchasing agreements of private corporations that operating international business in Thailand.

- To study processing time for procurement by purchasing agreements.

- To study means to increase efficiency for procurement by purchasing agreements of private corporations that operating international business in Thailand.

Expected benefits

- To know steps of procurement by purchasing agreements

- To know processing time for procurement by purchasing agreements

- To know means to increase efficiency for procurement by purchasing agreements

Research hypotheses

- To study on procurement by purchasing agreement of the Electricity Generating Authority of Thailand, in order to perceive operating's problems and obstacles.

- To study on problems and obstacles in procurements, in order to recognize ways to solves problems and increase efficiency of procurement operation.

Scope of the research

Population and samples

- Population for this research is procurement department's staffs, 40 persons.

- Samples for this research are procurement department's staffs that were selected by purposive.

Sampling method, 40 persons. 


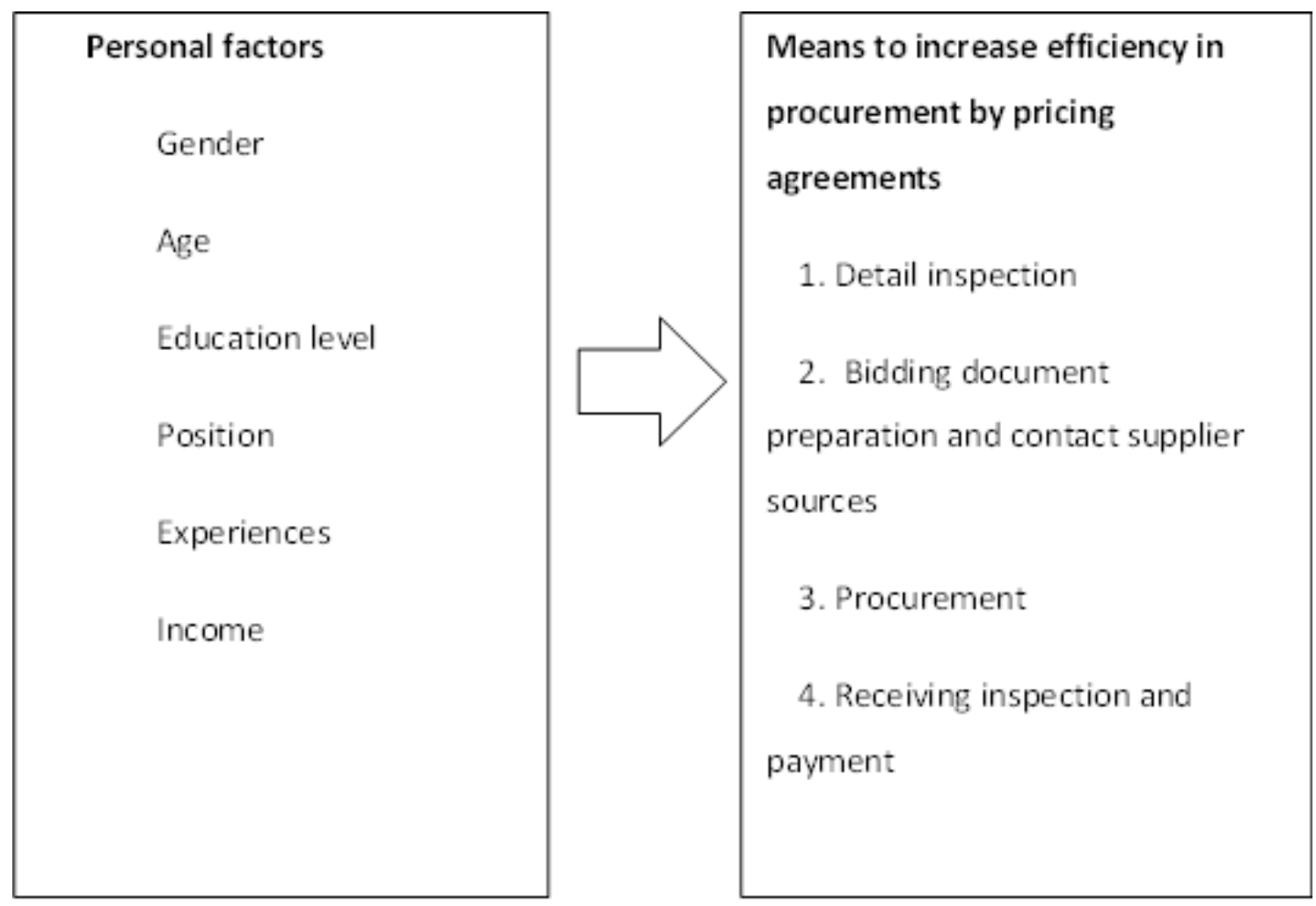

Picture 1.1. Conceptual framework

\section{Operation Methods}

This research is a survey research to study procurement methods on a case study of procurement by pricing agreement of private corporations that engages in logistics and international business. The study is following these steps:

3.1 Population and samples

3.2 Research instrument

3.3 Data collection

3.4 Data analysis

3.5 Statistics used in the data analysis

Population and Samples

1. Population for this research is staffs in procurement section of domestic supply and procurement department, 40 persons.

2. Samples for this research are staffs in procurement section of domestic supply and procurement department that have been selected by purposive sampling method, 40 persons.

\section{Research Instrument}

Instrument used in this research is a questionnaire on opinions towards procurement by pricing agreement of procurement section, which has been created for data collection. The questions are divided into 3 parts as follow:

Part 1: Questions on general information

Part 2: Questions on problems in procurement by pricing agreement
Part 3: Suggestions

\section{Data Collection}

Data was collected with 2 processes; first by review data, and second by field data. Furthermore, the data was divided into 2 types; primary and secondary data.

\section{Primary Data}

The primary data was gathered from 40 sets of questionnaire, where the respondents fill their answers by themselves. Then, the questionnaires are collected and checked for accuracy and completeness by the researchers, before being analysed by statistical methods.

\section{Secondary Data}

The secondary data was acquired from studies of various documents; such as textbook, articles, journals, documents, theses, and related researches. It was used to accompany with questionnaire design, data analysis, and conclusion of the results.

\section{Data Analysis}

Collected data was divided into 3 parts, which each part has been analysed as follow:

Part 1: Status of the respondent, frequencies and percentages were calculated, and reported in a table accompanied with description.

Part 2: Opinions of the respondents towards level of operation's problems. Collected data was calculated for 
frequencies and percentage, and reported in a table accompanied with description. The answers to the questionnaire were classified into 5 band scores, as follow:

Highest opinion level

High opinion level

Moderate opinion level

Low opinion level

Lowest opinion level indicated as indicated as indicated as indicated as score 5 score 4 score 3 score 2 indicated as score 1

Then the band scores are calculated for means and interpretation of the calculated means are specified as:

Mean $4.510-5.000$ is highest opinion level

Mean $3.510-4.500$ is high opinion level

Mean 2.510-3.500 is moderate opinion level

Mean $1.510-2.500$ is low opinion level

Mean $1.000-1.500$ is lowest opinion level

Part 3: Suggestions are for increasing efficiency of procurement by pricing agreements of the Electricity Generating Authority of Thailand, were presented in an essay form.

\section{Statistics Used in the Data Analysis}

Statistics that was used in this data analysis was descriptive statistics and expressing opinions regarding procurements and ways to increase efficiency in procurement by pricing agreement, including frequency distribution; percentage; mean; and standard deviation (S.D.)

Formula Used to Calculate Percentage

$$
P=\frac{f}{n} \times 100
$$

Where

$\mathrm{P}$ is percentage of samples

$\mathrm{f}$ is frequency that want to calculate

$\mathrm{n}$ is numbers of respondent or sample size

Formula Used to Calculate Mean

$$
\bar{x}=\frac{\sum x}{n}
$$

Where $\bar{x}$ is mean of samples

$\sum x$ is sum of overall scores

$\mathrm{n}$ is numbers of respondent or sample size

Formula Used to Calculate Standard Deviation

$$
S . D .=\sqrt{\frac{n \sum x^{2}-\left(\sum x\right)^{2}}{n(n-1)}}
$$

Where S.D. is the standard deviation of samples

$\mathrm{n}$ is numbers of respondent or sample size

$\sum x^{2}$ is sum of the squares of each score

$\left(\sum x\right)^{2}$ is the sum of each score squared

\section{Data Analysis Results}

A research on procurement methods of private corporations that engages in international business: a case study on procurement by pricing agreements.[13] A questionnaire is used to gather information from staffs in supply and procurement section of domestic supply and procurement department. The questionnaire then being analyzed; and the results of this study can be divided into 3 parts as follow:

1. Questionnaire on general information.

2. Procurement methods by pricing agreements of private corporations that engages in international business.

3. Suggestions

1. General Information

Table 1. Numbers and percentages of samples, classified by genders.

\begin{tabular}{|c|c|c|}
\hline Gender & Number & Percentage \\
\hline Male & 16 & 40.0 \\
\hline Female & 24 & 60.0 \\
\hline Total & 40 & 100 \\
\hline
\end{tabular}

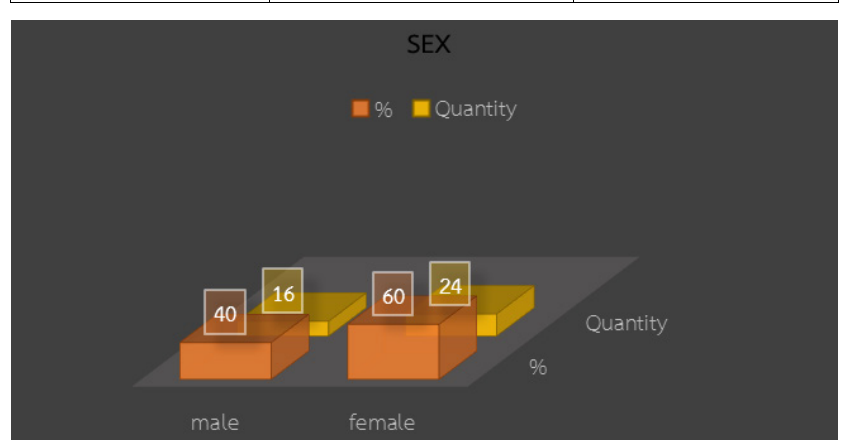

Picture 1. Chart shows percentages of the respondents, classified by Gender.

Table 2. Numbers and percentages of samples, classified by age ranges.

\begin{tabular}{|c|c|c|}
\hline Age & Number & Percentage \\
\hline $20-30$ & 10 & 25.0 \\
\hline $31-40$ & 17 & 42.5 \\
\hline $41-50$ & 9 & 22.5 \\
\hline $51-60$ & 3 & 7.5 \\
\hline Older than 61 & 1 & 2.5 \\
\hline Total & 40 & 100.0 \\
\hline
\end{tabular}

From table 2, showed that the respondents were mostly aged between 31-40 years old (42.5 percent), the seconds most respondents aged between 20-30 years old (25.0 percent), the third most respondents aged between 41-50 years old ( 22.5 percent), the fourth most respondents aged between 51-60 years old (7.5 percent), and the least respondents that respond to the questionnaire were older than 61 years old ( 2.5 percent). 


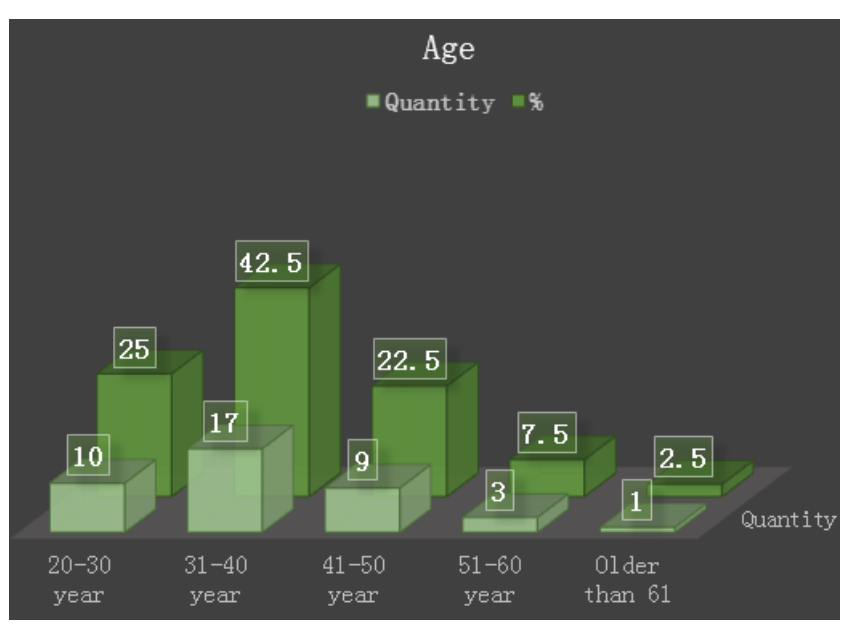

Picture 2. Chart shows percentages of the respondents, classified by age ranges.

Table 3. Numbers and percentages of samples, classified by education levels.

\begin{tabular}{|c|c|c|}
\hline Education levels & Number & Percentage \\
\hline Diploma & 5 & 12.5 \\
\hline Bachelor degree & 18 & 45.0 \\
\hline Master degree & 14 & 35.0 \\
\hline Higher than master degree & 3 & 7.5 \\
\hline Total & 40 & 100.0 \\
\hline
\end{tabular}

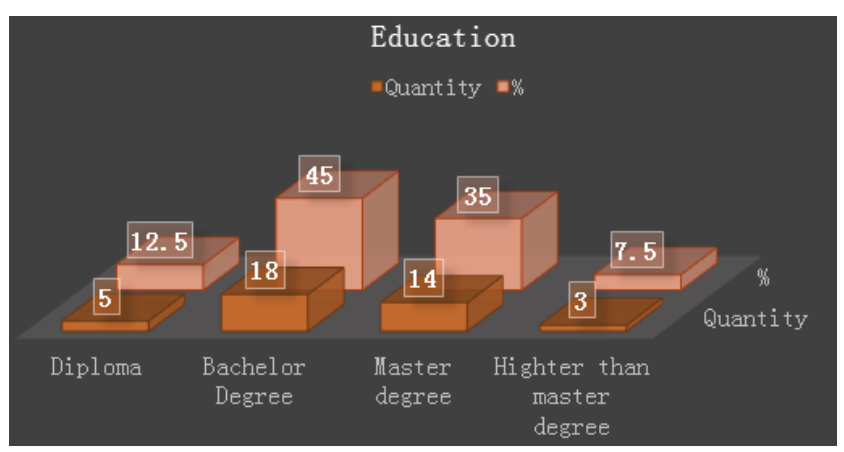

Picture 3. Chart shows percentages of the respondents, classified by education levels.

From table 3, showed that most of the respondents were bachelor degree graduates (45.0 percent), master degree graduates were the second most respondents (35.0 percent), the third most respondents were diploma graduates (12.5 percent), and the least respondents were those who have their education levels higher than master degree ( 7.5 percent).

Table 4. Numbers and percentages of samples, classified by work positions.

\begin{tabular}{|c|c|c|}
\hline Position & Number & Percentage \\
\hline Operational staffs & 19 & 47.5 \\
\hline Foreman & 16 & 40.0 \\
\hline Executives & 5 & 12.5 \\
\hline Total & 40 & 100.0 \\
\hline
\end{tabular}

From table 4, found that the most respondents worked as operational staffs (47.5 percent), the second most respondents work as foreman (40.0 percent), and the least respondents were executives.

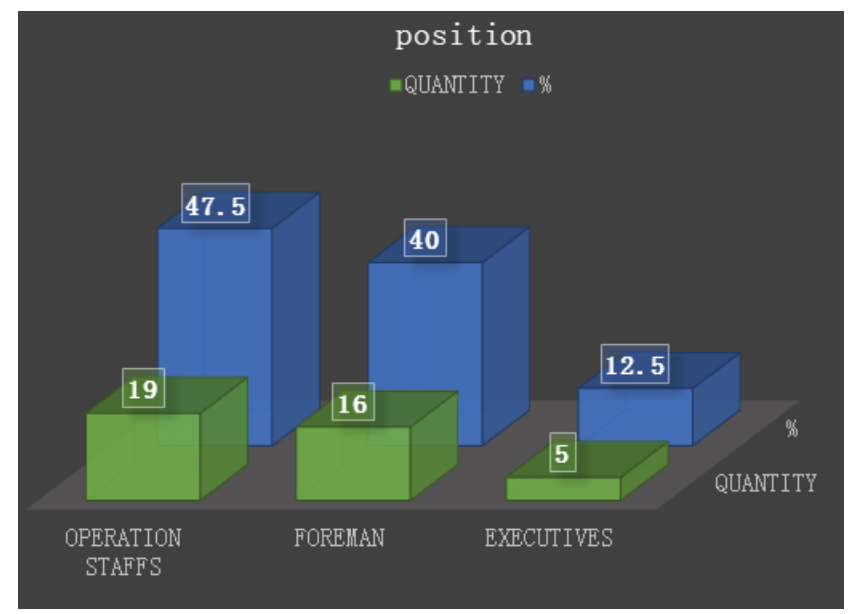

Picture 4. Chart shows percentages of the respondents, classified by work positions.

Table 5. Numbers and percentages of samples, classified by experiences.

\begin{tabular}{|c|c|c|}
\hline Experience & Number & Percentage \\
\hline $1-5$ years & 16 & 40.0 \\
\hline 6-10 years & 11 & 27.5 \\
\hline $11-15$ years & 6 & 15.0 \\
\hline $16-20$ years & 2 & 5.0 \\
\hline More than 21 & 5 & 12.5 \\
\hline Total & 40 & 100 \\
\hline
\end{tabular}

From table 5, found that the most respondents have their experience between 1-5 years ( 40.0 percent), the second most respondents have their experience between 6-10 years (27.5 percent), the third most respondents have their experience between 11-15 years (15.0 percent), the fourth most respondents have their experience more than 21 years (12.5 percent), and the least respondents have their experience between 16-20 years (5.0 percent).

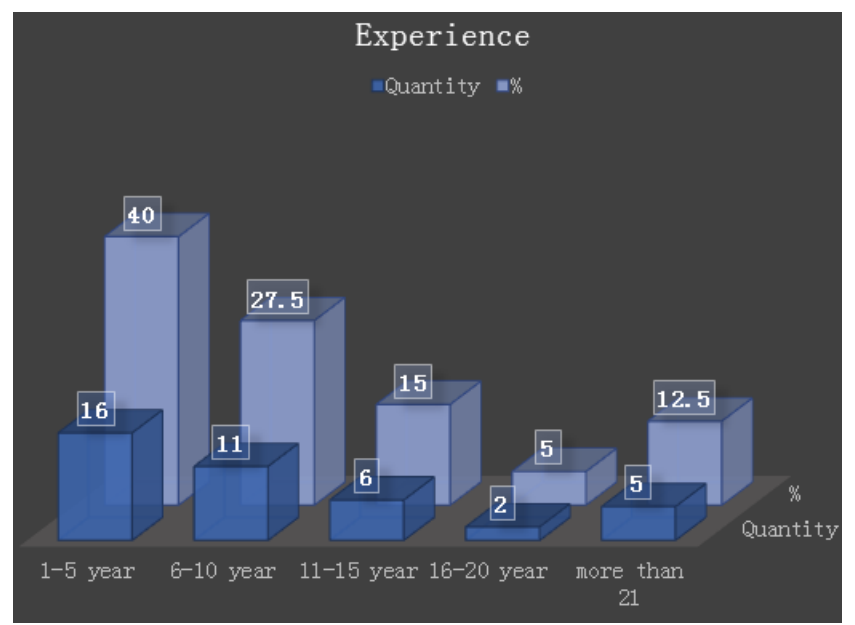

Picture 5. Chart shows percentages of the respondents, classified by classified by experiences 
Table 6. Numbers and percentage of samples, classified by incomes.

\begin{tabular}{|c|c|c|}
\hline Income & Number & Percentage \\
\hline $15,000-20,000$ Baht & 5 & 12.5 \\
\hline $21,000-25,000$ Baht & 8 & 20.0 \\
\hline $26,000-30,000$ Baht & 8 & 20.0 \\
\hline $31,000-35,000$ Baht & 5 & 12.5 \\
\hline $40,000-45,000$ Baht & 3 & 7.5 \\
\hline Higher than 50,000 Baht & 11 & 27.5 \\
\hline Total & 40 & 100.0 \\
\hline
\end{tabular}

From table 6 , found that most of the respondents have their income higher than 50,000 Baht (27.5 percent), the second most respondents have their income between 21,000-25,000 Baht, and 26,000-30,000 Baht (20.0 percent), the third most respondents have their income between 31,000-35,000 Baht (12.5 percent) and the least respondents have their income between 40,000-45,000 Baht (7.5 percent).

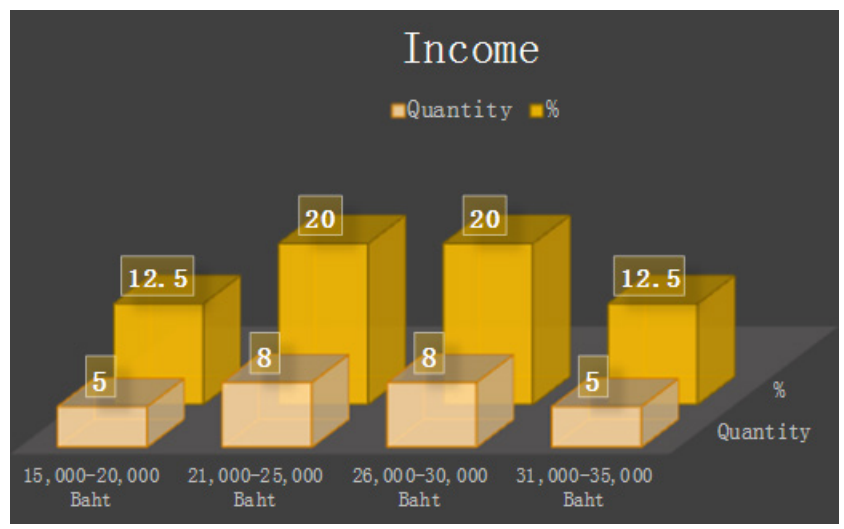

Picture 6. Chart shows percentages of the respondents, classified by classified by income.

Procurement methods by pricing agreements of private corporations that engages in international business: a case study on procurement by pricing agreements.

Table 7. Detail inspection works

\begin{tabular}{|c|c|c|c|}
\hline Detail inspection & Mean & $\begin{array}{c}\text { Standard } \\
\text { deviation }\end{array}$ & $\begin{array}{c}\text { Opinion } \\
\text { level }\end{array}$ \\
\hline $\begin{array}{c}\text { 1. Procurement staffs that } \\
\text { receive online requisition } \\
\text { form from requisite } \\
\text { persons }\end{array}$ & 4.13 & 0.85 & $\begin{array}{c}\text { High level } \\
\text { opinion }\end{array}$ \\
\hline $\begin{array}{c}\text { 2. Detail inspection of the } \\
\text { requisition forms }\end{array}$ & 4.00 & 0.75 & $\begin{array}{c}\text { High level } \\
\text { opinion }\end{array}$ \\
\hline $\begin{array}{c}\text { 3. Types and amounts were } \\
\text { indicated in supply } \\
\text { requirement notification or } \\
\text { procurement request }\end{array}$ & 3.83 & 0.59 & $\begin{array}{c}\text { High level } \\
\text { opinion }\end{array}$ \\
\hline $\begin{array}{c}4 \text { Audit systems, to } \\
\text { guarantee that regulations } \\
\text { were followed, are } \\
\text { available }\end{array}$ & 3.86 & 0.70 & $\begin{array}{c}\text { High level } \\
\text { opinion }\end{array}$ \\
\hline Total & 3.96 & 0.72 & $\begin{array}{c}\text { High level } \\
\text { opinion }\end{array}$ \\
\hline
\end{tabular}

From table 7 about detail inspection, found that most respondents have given their highest opinion on procurement staffs that receive online requisition forms from requisite persons (4.13 percent), the second highest opinion was on detail inspection of the requisition forms (4 percent), the third highest opinion was on whether audit systems, to guarantee that the regulations were followed, are available (3.86 percent), and the lowest opinion on whether types and amounts were indicated in supply requirement notification or procurement request (3.83 percent). Where combine mean was 3.96 with deviation 0.72 .

Table 8. Bidding documents preparation and contact supplier sources works.

\begin{tabular}{|c|c|c|c|}
\hline $\begin{array}{l}\text { Bidding documents } \\
\text { preparation and contact } \\
\text { supplier sources }\end{array}$ & Means & $\begin{array}{l}\text { Standard } \\
\text { deviation }\end{array}$ & $\begin{array}{l}\text { Opinion } \\
\text { level }\end{array}$ \\
\hline $\begin{array}{l}\text { 1. Easy to contact with } \\
\text { sellers or supplier sources }\end{array}$ & 3.82 & 0.63 & $\begin{array}{l}\text { High level } \\
\text { opinion }\end{array}$ \\
\hline $\begin{array}{l}\text { 2. seller records as well as } \\
\text { statistics of price and } \\
\text { amount are available }\end{array}$ & 3.95 & 0.50 & $\begin{array}{l}\text { High level } \\
\text { opinion }\end{array}$ \\
\hline $\begin{array}{l}\text { 3. estimate cost was } \\
\text { indicated in order to } \\
\text { compare with offering } \\
\text { price }\end{array}$ & 3.85 & 0.66 & $\begin{array}{l}\text { High level } \\
\text { opinion }\end{array}$ \\
\hline $\begin{array}{l}\text { 4. comparison to latest } \\
\text { buying price and/or from } \\
\text { various sellers in order to } \\
\text { get the best price possible }\end{array}$ & 3.82 & 0.71 & $\begin{array}{l}\text { High level } \\
\text { opinion }\end{array}$ \\
\hline Total & 3.86 & 0.62 & $\begin{array}{l}\text { High level } \\
\text { opinion }\end{array}$ \\
\hline
\end{tabular}

From table 8 about bidding documents preparation and contact supplier sources, most respondents found that seller records as well as statistics of price and amount are available has the highest frequency (3.95 percent), the second highest was estimate cost was indicated in order to compare with offering price (3.85 percent), the third highest frequency were comparison to latest buying price or from various sellers in order to get the best price possible, and easy to contact with sellers or supplier sources (with equal mean at 3.82 percent). Where combine mean was 3.86 with deviation 0.62 .

Table 9. Procurement works.

\begin{tabular}{|c|c|c|c|}
\hline Procurement & Mean & $\begin{array}{c}\text { Standard } \\
\text { deviation }\end{array}$ & Opinion level \\
\hline $\begin{array}{c}\text { 1. Fast and accurate } \\
\text { procurement }\end{array}$ & 3.80 & 0.72 & $\begin{array}{c}\text { High level } \\
\text { opinion }\end{array}$ \\
\hline 2. Appropriate procurement & 3.92 & 0.69 & $\begin{array}{c}\text { High level } \\
\text { opinion }\end{array}$ \\
\hline $\begin{array}{c}\text { 3. Procurement by } \\
\text { procurement staffs under } \\
\text { supply request forms or } \\
\text { approved procurement } \\
\text { licenses }\end{array}$ & 3.82 & 0.55 & $\begin{array}{c}\text { High level } \\
\text { opinion }\end{array}$ \\
\hline $\begin{array}{c}\text { 4. Preparation of purchasing } \\
\text { order and its copies for } \\
\text { accessories; which are } \\
\text { receiving inspectors, } \\
\text { procurement informants, } \\
\text { accountants, or finances }\end{array}$ & 4.56 & 4.88 & $\begin{array}{c}\text { High level } \\
\text { opinion }\end{array}$ \\
\hline Total & 4.02 & 1.71 & $\begin{array}{c}\text { High level } \\
\text { opinion }\end{array}$ \\
\hline
\end{tabular}


From table 9 about procurement, found that the highest opinion from the respondents was given to preparation of purchasing orders and its copies for accessories; which are receiving inspectors, procurement informants, accountants or finances (4.56 percent), the second highest was appropriate procurement (3.92), the third highest was procurement by procurement staffs under supply request forms or approved procurement licenses (3.82 percent), and the lowest was fast and accurate procurement ( 3.80 percent). Where combine mean was 4.02 with deviation 1.71.

Table 10. Receiving inspection and payment works

\begin{tabular}{|c|c|c|c|}
\hline $\begin{array}{l}\text { Receiving inspection and } \\
\text { payment }\end{array}$ & Mean & $\begin{array}{r}\text { Standard } \\
\text { deviation }\end{array}$ & $\begin{array}{c}\text { Opinion } \\
\text { level }\end{array}$ \\
\hline $\begin{array}{l}\text { 1. identifying authorized } \\
\text { receiving inspectors }\end{array}$ & 3.87 & 0.56 & $\begin{array}{l}\text { High Level } \\
\text { opinion }\end{array}$ \\
\hline $\begin{array}{l}\text { 2. counting of amounts and } \\
\text { types of received supplies } \\
\text { with purchasing orders or } \\
\text { invoices, with at least } 2 \\
\text { inspectors' signatures }\end{array}$ & 4.05 & 0.68 & $\begin{array}{l}\text { High level } \\
\text { opinion }\end{array}$ \\
\hline $\begin{array}{l}\text { 3. specifying department } \\
\text { that responsible for } \\
\text { payment inspection }\end{array}$ & 4.00 & 0.72 & $\begin{array}{l}\text { High level } \\
\text { opinion }\end{array}$ \\
\hline $\begin{array}{l}\text { 4. Receipt that has been } \\
\text { paid should be marked to } \\
\text { avoid repeated payment }\end{array}$ & 3.95 & 0.55 & $\begin{array}{l}\text { High level } \\
\text { opinion }\end{array}$ \\
\hline Total & 3.96 & 0.62 & $\begin{array}{c}\text { High level } \\
\text { opinion }\end{array}$ \\
\hline
\end{tabular}

From table 10 about receiving inspection and payment, most of the respondents have given their highest opinion to counting of amounts and types of received supplies with purchasing orders or invoices, with at least 2 inspectors' signatures ( 4.05 percent), the second highest opinion was specifying department that responsible for payment inspection, (4.00 percent), the third highest was receipt that has been paid should be marked to avoid repeated payment (3.95 percent), and the lowest opinion was identifying authorized receiving inspectors (3.87 percent). Where combine mean was 3.96 with deviation 0.62 .

\section{The Results}

From the research, the survey found that the frequency of online bill of lading from authorities is high. Details of the bill of lading checking and review are contained in priority level two. Both of two causes should reduce the period of operation. In section of conveyed parcels, or ask them to supply, specified category or list parcels and a system of checks to make sure there is compliance with the prescribed rules. [3] discusses the meaning of the procurement that is a process of companies to buy or sell goods or services. It achieves the objective of a business. It is depended on time, cost in right quantity, quality and price in the right source. [11]

\section{Document, Contact and Distribution}

From the information about sourcing and suppliers contact, the survey found that the vendor registration preparation that includes price and quantity are the most important in this part. It relates to price quotation from vendors. Moreover, price is different from organizations that are easy to source raw materials. It can compare the prices and find out the lowest price. It is a strategy of procurement. The different procurement are depended on products, service, resource, and process [16],[17]

1. Purchase requisitions receiving analyzes the type of things and the amount of purchase

2. Study the market of source procurement and vendor

3. Request for quotation to the seller multiple sources

4. Receive and analyze the requisitions, quotes from

5. Vendors, vendor selection, and the best conditions.

6. Calculate the price of the items that are ordered correctly.

7. Send a purchase order to the sellers

8. Follow-up according to the contract, or contact.

9. Report of the analysis

10. Analyze and verify invoice of the vendor to payment

\section{Sourcing}

From the sourcing data that employees follows purchase order or approve, the survey found that purchasing order creation and copy are the most important the procurement, inspection, or financial accounts. There are reviews in most levels to meet the demand in the good and management. These are the priority of the preparation by staff based on a need to supply parcels and have a supply of the correct price. It is consistent with the procurement administration theory. [7] She suggested that procurement is crucial for all organizations, whether Government or the private sector an analysis of awareness. The real issue is therefore considered necessary by considerations in the theory as follows:

1. Recognition of Need is to buy multiple products through the purchasing department that has a great system at work. Prediction is usually set up with the forecasting of the department as a user of those products. Because of the prediction, demand is right and sufficient each time. In addition, it may need to seek an alternative item, as well as source materials with alternative for use in times of need.

2. The Description of Need is to recognize the problem, and then all parties know that the match correctly. What you want is exactly? What are the results? Sourcing would not make the change. This will cause synchronization conflicts and various units in the organization.

3. The establishing Specification is the first of the procurement. It must be relevant, is that "it will buy anything .....What to buy". It isn't easy because the organizations concern price and duty that both of them are relevant.

4. Selection of Sources is selecting the source of the request. For a specific item or items that are brand vision rights (Patented Items), sales may have only one source. Otherwise, there may be several items which we finally have to choose only. However, only the option to buy at the 
current price, depending on the source, may be purchased by many sources. In order to maintain its popularity from other sources provided for security or insurance policies, mutual contributions.

5. Ascertaining the Price is during the source selection process. Sales of purchasing department will need to make a purchase price to the news about tracing with. Price is an important factor per selection. Purchases agreement assumes the price is interesting, important and necessary in the contract. Both parties will need to bind together the legal. Procurement in government has to follow regulation of procedure law. It considers in terms of competition among those offered by, and is fairly transparent. This method is very good, but it has weaknesses in that requires too much time, since price comparison study the price list or quotes from suppliers.

6. Placing the Order is the main task of the purchasing department, which every time it is written, as a testimony to the mutual both parties

7. The Order Expediting and Follow-up: When organization issues a purchase order successfully, it does not mean that there will not in charge of purchasing. Every purchasing department will need to follow up or order tracking although the seller is selected until it is reliable for us.

8. Checking Invoice: the purchasing department should double check invoices that it is alert products are arrive or not.

9. Maintenance of Vendor Relations is to maintain a relationship with the seller. It is the important tasks of the purchasing department relationships. Arising from the trust each other, someone said that the value of the purchasing department is a measure of its popularity among vendors. Operation of the purchasing department can achieve the aim that is easy to make and receive payments. [9]

\section{Check and Payment}

In check-in and payment process, it found that parcel receiving with purchasing order requires 2 inspectors' signatures. Moreover, department is fixed for time reduction and error prevention and payment.[6] showed that parcel receiving was in a procurement process are transport by trucks, train, boat and airplane. Parcels are arrived in custom as they are counted and checked with different documents. They are depended on parcel declaration, business and government policy. These are expenditure of organization. However, the receipts are requirement from a management's policy. All organization should follow all steps. Therefore, parcels is recorded and accounted with parcel' value. The customer can receive all parcels whenever this process is completed inspection document only. [7]

\section{Suggestions}

\section{Detail Inspection}

Supply staffs should be inspecting details in supply receiving forms and report to chief of the department.

\section{Bidding Documents Preparation and Contact Supplier Sources}

There should be direct contact with supplier sources as required by company's regulation.

\section{Procurement}

Supply staffs should be completely and correctly indicate and enclose every time when issue purchasing/procurement orders.

Supply staffs should always indicate defects liability in purchasing/procurement orders

Procurement by pricing agreements often is procurements of the same materials, similar usability requirement. So, the chief of department should reiterate responsible staffs to plan for joint procurements of the same material and the same usability requirement.

\section{Receiving Inspection and Payment}

There should be receiving inspection on the day that sellers or suppliers deliver the supplies, and should be done as soon as possible. Headings of subsections should be in Time New Roman 12-point bold with initial letters capitalized (Heading 2). (Note: For sub-sections and sub-subsections, a word like the or of is not capitalized unless it is the first word of the heading.)[3]

\section{REFERENCES}

[1] Adul jaturongkun (2004), "Purchasing," Bangkok: Thummasart university Publishing. Vol. 4, pp. 10, 11, 20-22, 27, 255-258.

[2] Al-Abdulqader, H. A., Al-Mubarak, A. I., \& Al-Mulla, U. M. (2014). U.S. Patent No. 8,706,569. Washington, DC: U.S. Patent and Trademark Office.

[3] Anurak borirak (2007), "Purchasing management in Thailand." ITL trad media's publisher. Bangkok. Vol.1, No.1, pp. $164-172,178-180$.

[4] Bergman, M. A., \& Lundberg, S. (2013). Tender evaluation and supplier selection methods in public procurement. Journal of Purchasing and Supply Management, 19(2), 73-83.

[5] Chasey, A., Maddex, W., \& Bansal, A. (2012). Comparison of public-private partnerships and traditional procurement methods in North American highway construction. Transportation Research Record: Journal of the Transportation Research Board, (2268), 26-32.

[6] Duangjai jandasang (2015) Factors affecting the service of transportation use outbound freight case study of operators bkp Bangkok, 52-67

[7] Dzeng, R. J., \& Lin, Y. C. (2004). Intelligent agents for supporting construction procurement negotiation. Expert Systems with Applications, 27(1), 107-119.

[8] Falagario, M., Sciancalepore, F., Costantino, N., \& Pietroforte, R. (2012). Using a DEA-cross efficiency 
approach in public procurement tenders. European Journal of Operational Research, 218(2), 523-529.

[9] Greenwood, D. (2001). Subcontract procurement: are relationships changing?. Construction Management and Economics, 19(1), 5-7.

[10] Logisticscorner. (2552), “The procurement process.” [On-line Available]: http:// http://logisticscorner.com

[11] Mahmood, S. A. I. (2010). Public procurement and corruption in Bangladesh confronting the challenges and opportunities. Journal of public administration and policy research, 2(6), 103.

[12] Ng, T., Luu, D., \& Chen, S. (2012). Decision criteria and their subjectivity in construction procurement selection. Construction Economics and Building, 2(1), 70-80.

[13] Procurement (2013), "Manual operation of the Electricity Generating Authority of Thailand Nonthaburi.
[14] Procurement price by agreement. (2009), Guide cognitive supplies and supply sides. Nonthaburi

[15] Regan, M., Smith, J., \& Love, P. (2011). Infrastructure procurement: learning from private-public partnership experiences 'down under'. Environment and planning C: Government and policy, 29(2), 363-378.

[16] Slobodeanu, S., \& Munteanu, N. (2014). Considerations on applying the analysis matrix methods of the risks within the audit of the procurement-payment cycle. Ecoforum Journal, $3(2), 11$.

[17] Sumana Upo (1995), Purchasing and Inventory Management, Bangkok: Publisher's shonpim.

[18] Thongrawd, chairit. (2015). The realization of integrated marking communications that affect purchasing behaviors of adolescent girt cosmetics in Bangkok. Journal of Management Science, 1(1), 111-125. 